\title{
Literary Artists and African Witchcraft: The Unending Search for Solutions
}

\author{
Simiyu Kisurulia \\ Department of Languages, Linguistics and Communication, School of Arts and Social Sciences, University of Kabianga, Kenya
}

Copyright $\mathrm{C} 2017$ by authors, all rights reserved. Authors agree that this article remains permanently open access under the terms of the Creative Commons Attribution License 4.0 International License

\begin{abstract}
Humankind is the most rational and manipulative being. Men and women will always look for solutions to problems and issues affecting them. This search for solutions is at the first instance located within the natural sphere. When nature fails to provide adequate answers, human beings often turn to the spiritual sphere for answers. Witchcraft also referred to as sorcery or black magic, falls anywhere between the natural and the spiritual or supernatural. The practice is an age-old one and, according to anthropological studies, cuts across all the continents of the world. This paper concerns itself with the rendition of the practice from a Swahili literary perspective. The analysis aims at attempting to understand the existence of the practice, its social effects and reasons for its persistence in the society. We analyse the practice of witcheraft as depicted in two Swahili works of art namely Kisima cha Giningi/The well at Giningi (Abdulla, 1968) and Hatimayanguniipi?/What is my destiny?(Chipeta, 2010). These two novels present the practice in two different ways thus attracting the attention of the reader to curiously and critically interrogate the whole practice. The two have been purposively selected as they depict the practice and have been subjected to content analysis to unearth the inherent belief concerning witchcraft and the artist's point of view concerning the same. The analysis is guided by realism and social dynamic theory. It is baffling that even with the advancement in science and technology, and even with the more practical solutions offered by major religions of the world, such a vicious practice that simply escapes human understanding still persists. As such, this analysis widens our perception of the practice of witchcraft as a persistent social practice.
\end{abstract}

Keywords Witchcraft, Literary Art, Swahili, African, Sorcery, Effect

\section{Introduction}

Witchcraft is no new practice. It is one of those practices that modern man would label 'primitive'. It is primitive indeed because its intentions are never progressive. It is applied discriminatively and for selfish purposes. Again it is done in secrecy so much so that when one feels it is worthwhile to break into it and even understand it, the effort is never fruitful. It is a game of hide and seek. Witches hardly operate in the open. They are not open to public scrutiny. Yet by some stroke of luck, it appears their magic works and in the end they achieve whatever they intend to happen. Unfortunately, in almost all cases, they seem to be hell-bent on causing disharmony in the community. This position is for those who believe that actually witchcraft exists. The contrary is also evident in society. There are those who do not believe in witchcraft. It is hard to convince such of the existence of witchcraft. Yet whether one holds witchcraft beliefs or not, the mention of it sends a cold chill down everybody's spine. We may take the position of not believing in witchcraft but when its consequences are mentioned, we are unable to take an affirmative stand. This is the ambivalence that is discussed in the current article.

In order to make sense out of the events recounted in the two novels, we make recourse to realism as well as social dynamics theory. To take a simple view of what realism is, Hawthorn [1] notes that a novel is realistic if the events recounted, the characters and the setting model everyday life. This means that whatever the artist writes about should be as close as possible to everyday experiences of people. Even though the events are fictive, the writer draws material for the piece of work from everyday life. Thus the artist turns real events into fictive ones. Indeed Eagleton [2] notes that literature is deeply conditioned by its social context and any sound criticism of the same should not omit this fact. Such understanding raises the question of the difference between art and history but for our case we do not wish to delve into that debate. On the other hand, Forsyth [3] states that social dynamics theory seeks to analyse and explain forces that operate in social interactions. It seeks to explain the process of group formation, group characteristics and why people remain loyal to groups that they join. In our view, these two theories supply us with the necessary toolkit for 
understanding the mechanisms that operate in witchcraft. With the help of these critical approaches, therefore, the two novels are subjected to content analysis whereby events that depict witchcraft are purposively sampled and analysed.

\section{The Concept of 'Witchcraft' Explained}

The concept of witchcraft is closely associated with its sister concepts 'sorcery' and 'evil magic'. Indeed in many African languages, the distinction among these terms is elusive and almost non-existent. Oftentimes, one will find them being used interchangeably. Nevertheless, it is possible to discern some minor differences in the application of the concepts. Evans-Pritchard [4] defines witchcraft as the innate, inherited ability to cause misfortune or death. On the other hand, he defines sorcery as the performance of rituals, the uttering of spells, and the manipulation of organic substances, such as herbs, with the conscious intent of causing harm. From these definitions, we note that both terms refer to use of some powers to cause harm. The difference is that in witchcraft, no substance is used. All that the witch needs is to arouse intent to cause harm and, in a magical way, the harm is caused. By contrast, a sorcerer has to use some substance to cause the intended harm. In either case, harm is the end result hence the widespread confusion of these concepts. Middleton and Hunter [5] are even more succinct when they state that the power of witcheraft is mystical and innate. They go on to say that the witch need merely wish harm to his victim and his witchcraft then does this. The witch only needs to feel annoyance or jealousy against someone and this feeling sets in motion the powers of witchcraft against the victim. The witch needs no herbs, charms or any such organic substance to affect the harm. On the contrary, Middleton and Hunter explain that sorcerers use 'medicines' to harm those against whom they bear ill will. They use such things as roots, leaves, bodily effluvia, carcasses of animals and so on to affect their sorcery. In terms of effect then the two terminologies mean the same. They have the same result - harm.

Bongmba [6] offers us a good example of use of terminologies to explain the practice of witchcraft among the Wimbum of Cameroon, West Africa. Among the Wimbum, witchcraft is referred to using three closely related terms. One of these is bfui, which refers to a neutral ability to perform tricks and magical activities. This is therefore closer to magic and has no intention of harm. However, brii refers to performance of malevolent acts through some alleged power such as causing rain to fall or bringing disruption to a gathering. Yet brii can also be used in a light-hearted way such as accomplishing with ease something that others had previously had trouble with. In this case then, brii can be both evil or merely magical (intended for tricks). In its negative sense, brii equates witchcraft since it depends on mystical power. The sister term to brii is $t f u$ which may mean something positive or negative depending on use. The term $t f u$ is used to refer to various activities that may include the ability of foresight to causing another's illness or death. Evident from these definitions is the duality of the terms used to describe witchcraft. They may refer to good or evil at the same time. It is only the actual act that specifies the meaning.

In Kenya, the belief in witcheraft is widespread in many communities. This can be deduced from the terminologies of witchcraft that abound as well as the ease with which any community member can explain the belief. Among the Luhya of Western Kenya, a witch is called omulosi. Yet this term includes several meanings ranging from mere wizardry (which in most cases has no harmful intent apart from scaring people during the night) to actual malevolent powers of harm. The most widespread meaning of the term omulosi, however, is one who has evil powers be it through the practice of sorcery or witchcraft. In this community, to counter effects of witches, there is another person referred to as omulakusi or omung'osi (diviner), who, if 'powerful enough', can use his or her mystical powers to neutralize the acts of the witch or sorcerer. The term omulakusi can also be very broad in meaning to include a soothsayer or a prophet and as such the person of this stature is a saviour to the community and cannot be associated with the evil powers of the witch. In such case then, the term equates $t f u$ (in some respects) of the Wimbum. The Luo of Western Kenya refer to a witch as 'jajuok' whereas the Kipsigis of Rift Valley call such a person 'banindet'.

The Swahili of East Africa use the terms uchawi (also ulozi), uramali or sihiri to refer to witchcraft. However, uchawi is more generic in meaning and may cut across many malevolent activities hence equating in meaning to witchcraft. The other two terms, uramali and sihiri, are more reserved for sorcery where the sorcerer uses some organic substances to cause harm to the victim. Mbiti [8] uses the terms witchcraft (dependence on pure mystical power tapped to harm people or their property), sorcery and evil magic (in these two cases the force of the mystical power is spoken to the 'medicine' used to cause harm).

Evident from these few examples is the fact that witchcraft is a belief that is common in most Kenyan persons or property. Evident from these examples is the widespread nature of beliefs in witchcraft in Kenya. Ashforth [7] notes the same when he states that witchcraft is a commonplace feature of life in Soweto (South Africa) meaning belief in witcheraft is not alien on the African continent.

In this article, therefore, we look at the practice of this person known among the Luhya as omulosi (the practice is referred to as obulosi). We use the meaning as captured in the Swahili term uchawi. Witchcraft (obulosi among the Luhya otherwise uchawi in Swahili) aims mainly at causing harm to whomever it is directed at. Its actual potency is the question in point. Yet the practice is not questionable as it still exists as reflected in works of fiction written from a realist perspective. Views of literary artists appertaining to the practice are the ones that this article examines. 


\subsection{The Spiritual Dimension of Witcheraft}

As it has already been alluded to, witches possess mystical powers. The African view of the universe is that it is in two parts namely, the visible and the invisible [9]. The former is believed to be inhabited by God and spirits while the latter, the physical world, human beings. Thus, the same universe is populated by three beings: God, spirits and humans. These three beings are the ones that have power of action and can manipulate the other beings in the world as they will. Their power is mystical and God is its ultimate source is God, the creator of human beings and spirits. God therefore has apportioned the same power to spirits and some human beings. It appears that spirits have more of this mystical power and can use it benevolently or malevolently to harm human beings. Mbiti [9] argues that the universe is governed by a mystical order in which God is the highest in hierarchy, followed by spirits and lastly humans. He goes on to say that belief in such an order is clearly seen in the practice of traditional African medicine, magic, witchcraft and sorcery. From this exposition we gather that witches are among the few human beings who have been privileged to have access to the mystical powers that govern the universe. Unfortunately, they tap these powers to harm others hence their practice is referred to as evil magic, witchcraft or sorcery. Therefore, the discussion herein is centered around the reality and effects of use of these mystical powers to harm others.

\section{Swahili Literature and the Question of Witchcraft}

The question as to whether witchcraft really exists or is a hoax remains unanswered to-date. Many efforts by anthropologists to unravel this mystery have actually come to naught [10]. One reason for this state of affairs is that the whole practice is shrouded in mystery [11]. Whereas some claim to have the powers of witcheraft, they hardly can share secrets about those powers and how they work. Consequently, whatever knowledge most of us have about witchcraft is based on stories we hear, events we see in real life (whose occurrence are attributed to acts of witchcraft) and mere guesswork. This could be the factor that has driven literary artists to attempt to shed light on this 'top-notch' secret. Yet hard as they may try to find answers to the mystery, they end up not doing much to change the understanding of the practice.

Swahili literature has not been short of delving into the question of superstition and African witchcraft. Mbogo in his play, Ngoma ya Ng'wanamalundi [12], treats this subject at length. In this play, a number of characters suffer the malevolent effects of witches some of whom acknowledge that they are real technicians at witchcraft. Witchcraft is also alluded to in Pango [13] where one of the main characters, Ngwese, accuses his political opponent, Katango, of practicing witchcraft on him. Similar accusations of the practice of witchcraft are to be found in Kufa Kuzikana [14] where one ethnic community (the Korosho) accuses the other (the Kanju) of practicing witchcraft. These few examples point to the fact that witchcraft is both a belief and practice that is not alien to Swahili literary artists writing from a realist point of view.

\section{Is Witchcraft a Reality or Mere Fiction?}

There are two dichotomies to the answer to this question. One is an outright 'yes'. But when the hard question of proof comes to bear, we are left empty-handed with no real evidence to support our answer. So again it is 'no'. Yet even in saying 'no' we could be doing so half-heartedly. The 'no' may quickly be prompted by modernity (the belief in science and technology) and our religious beliefs (or what is expected of us by our religions). Here then, we are left tossing between two answers with none seeming to carry the day by assuring us that indeed it is the unquestioned case. This ambivalence is not only in real life situations but is also the case in literature as shown in the analysis that follows.

\subsection{Witchcraft is a Reality}

The first side to the dichotomy of whether witchcraft really exists and is potent or not is to simply go with what we see and hear in our societies. It is real and potent; it exists! After all even major religious beliefs in the world attest to it. Before gaining release of the people of Israel from Egypt, both Moses (for the Israelites) and the Egyptian magicians engaged in a protracted game of magical might [15]. In this show of power, many magical activities ensued some of which were very disastrous to the community. Such disastrous activities could be likened to acts of witchcraft which in many cases cause disaster.

Chipeta [16] posits that witchcraft beliefs and practices are real and potent; they exist. There are witches in our various societies and there are those who seek their services. These two stakeholders in witchcraft (witches and members of the society seeking their services) gain from the practice (be it practically or psychologically). Chipeta's novel is based on the life of Charles Kulwa who rises from very humble backgrounds to a person of import in his society. His life is full of sheer determination by one who meets so many obstacles on his way to success. His parents were so poor that they could not afford to educate him. But due to their conversion to Catholicism, their parish priest, Fr. Albert, takes Kulwa to learn at the local seminary. Unfortunately, he does not complete his education at the seminary. He is expelled on grounds of having a love affair with a village girl, Adela, something that is against rules of the seminary. Expulsion from the seminary does not deter him from remaining focused and hard working in his village church. 
Within a few months of his stay in the village after expulsion, he turns around the church choir. Similarly, he turns around his small Christian community. These achievements are received with sheer amazement by the parish priest who is so happy that he sponsors him for education in Switzerland. In Switzerland, Kulwa does not disappoint either. He does so well in his education that he comes back to his native African country as a qualified gynaegologist.

On coming back to his native country, Tanzania, Dr. Kulwa is employed by the same priest who sponsored him. $\mathrm{He}$ works for a long time at the Catholic Mission hospital. He enjoys very cordial relations with the foreign priest. But when the foreign priest leaves and the mission are taken over by a local native priest (Fr. Zika), Dr. Kulwa's woes begin. Fr. Zika withdraws all the privileges that Dr. Kulwa enjoyed while working with Fr. Albert. This makes the going so hard for him that he hardly can manage to run his own family. This prompts him to think of new ways of making ends meet in his life. He delves into politics. It is politics that change Dr. Kulwa's life completely. On the economic side, he gets contented since he amasses a lot of wealth during his first term as a politician. But on the social front he is confronted with a practice he hitherto had not been acquainted with.

In the process of changing events of his life, Kulwa joins two groups; one formal (politics) and the other informal (the group of those who believe in the practice of witchcraft). The compelling reason why he joins both groups is because he wants to be economically stable so that he can cater for his family adequately. This basis for joining groups is explained clearly by the social exchange theory that states that groups are formed on the basis of reward-cost outcomes; the balance theory that sees individuals joining groups that will help them attain their goals and the social system theory propounded by Homans that sees group formation arising from the need by individuals to interact in order to solve problems, reduce tension, attain goals and achieve balance [3]. Having fallen out of favour with Fr. Zika and finding that he could nolonger afford to maintain the lifestyle he was used to during Fr. Albert's tenure, Dr. Kulwa resolves to join politics (which is well paying). However, this resolution does not come impulsively. Rather, it is based on his seeking opinions of many others on how he can change his fortunes. Indeed what this shows is that in the social world decisions are based on rational and purposive action by individuals [17].

In order for Kulwa to win a political seat without much ado, he realizes that he has first to enlist a team that will steer his campaign successfully. On finding this team, he learns that it is composed of various departments including that of the use of witcheraft to win in politics. At the first instance he finds this strange but since he is focused on winning a political seat, he has no option other than accepting all that the campaign team tells him. It is on this basis that Kulwa joins witcheraft beliefs and practices that hitherto we haven't seen him get involved in. Dr. Kulwa's induction into politics is full of superstitious and witchcraft activities (chapter 17).
The induction ceremony is conducted by the campaign committee led by Mabula. After Mabula's speech, he asks other members of the committee to talk and specifically state what their role is as members of the campaign team. The first to take the podium is an elderly man called Chakupewa. He introduces himself thus: "Apa mimi ni mukulu wa opelesyeni zya chiganga au jina lingine kamati yenye wanasema ya Ufundi kwenye uchaguzi" (I am the head of witchcraft operations or in other words the Technical committee of this campaign team). Even based on this highly broken Kiswahili, we note the importance attached to witchcraft when it comes to matters politics. It is interesting that the chairman of this committee gives the first opportunity to a 'mganga' (witch). And the witch does not mince his words. He categorically states his role in the campaign process (Hatima, pp. 102-103). Note how the narrator emphasizes the position of this man by foregrounding it. He is the head of the Technical wing of the campaign committee. The word "Technical" is written using a capital $\mathrm{T}$ even when it is appearing in the middle of the sentence showing the importance attached to the activities of witchcraft in politics. Yet in this case, this witch seems to be endowed with many more attributes. He introduces himself also as a traditional herbalist able to treat all kinds of maladies including tuberculosis, gonorrhea, syphilis, HIV-Aids and harm caused by genies. He concludes his speech by stating that he has the powers to pay back whoever wrongs the other. And the 'medicine' for this revenge? He uses 'chipembe' or 'lupekeso' or 'ladi'. Now, we would need interpretation by one from the Sukuma community to know what 'lupekeso' is since it is not a Swahili word. Nevertheless, from the other two words, 'chipembe' (possibly a 'horn' used by witches) and 'ladi' (wrong pronunciation of 'radi' i.e. lightning), we gather that these three words are synonyms. They refer to a kind of witch power that is used to pay back (retaliate) whoever has wronged the other. And this mystical power is no mean one. It equates to the brii among the Wimbum of Cameroon. This is meant to show that this man, Chakupewa, is no easy walk. $\mathrm{He}$ is not merely a herbalist but also possesses powers of witchcraft which he puts to use when the situation calls for it. This could be the reason why during the entire session that he talks, all other members of the committee listen quite keenly. And when he concludes his speech, he is applauded, something that is not accorded to the chairman, Mabula. It means Chakupewa's position and powers are held in awe. He is one of the kingpins of the campaign team since his powers are very important for the success of the campaign. What we see later of these powers has to do with witchcraft and none of the herbal practices adduced to in the introduction. Chakupewa's role in this campaign team is thus definitive. In social dynamics, he enjoys quite high status because of his role in this group. It appears he is the only one in the group with such strong mystical powers that cannot easily be countered.

Still during the speeches to 'congratulate' Dr. Kulwa for accepting to fly the flag of the Gika during the campaign, 
another member of the committee, Magadula, introduces himself as a long serving 'mganga' (read this as 'witch') whose speciality is 'egeseleyi' (a corruption of $\mathrm{x}$-ray) (Hatima, p. 103). By 'a specialist' in matters $\mathrm{x}$-ray, what Magadula means is that he is an expert in witch practices that penetrate human beings and make them act as the witch desires. That is why he goes ahead to explain his abilities. He says he is a specialist of a 'drug' called nsamba which when a person applies on self makes people automatically follow (support) the person who has applied it. The user may put this 'drug' in his pocket or in his mouth or apply it on his body. It can also be applied on food to be eaten by people. Once used, it makes all and sundry to come on the side of whoever has applied this 'medicine'. We can see how useful his 'medicine' is especially for a politician who desires votes from the masses. Magadula is emphasizing the importance of his 'medicine' and that is why when through with his speech he is also applauded unlike the chairman, Mabula. Magadula comes out as a sorcerer. His chemistry involves use of herbs to change the functioning of people in favour of whoever applies those herbs on self. Now, this appears to be another very powerful individual for Kulwa since he will enable him get as many votes as long as he applies Magadula's 'medicine'.

The final person to talk during this ceremony is Masawe. $\mathrm{He}$ is the one who makes it clear that all that the other two speakers (namely, Chakupewa and Magadula) have been talking about is witchcraft. Masawe comes out as a convert to Christianity but who is keen on the powers of witchcraft. In his speech, he makes reference to Jesus (Christ, the Saviour among Christians) and Mary, Jesus' mother. He concedes that among his clans-people, they did not know much about witchcraft but since gaining knowledge about it they have started buying the trade (witchcraft). Masawe finds witchcraft so exciting that he opines that the community is failing to put to use a big economic asset which they could exploit (read this as 'manufacture') and sell to others for economic gain just like the Americans sell nuclear weapons! (Hatima, p. 104). From Masawe's confession, it appears that Christianity has failed to erase witchcraft beliefs among some of its African followers.

This important induction meeting ends with an actual act of witchcraft or superstition (Hatima, p. 105). Chakupewa is asked by the committee chairman to administer an oath of secrecy. Specifically, this is administered on Dr. Kulwa who is the new player in the game of politics. Cuts are made on his spine, private parts and joints and some black ash is rubbed in. This oath binds Dr. Kulwa to the group and his political agenda. As Chakupewa asserts, this 'medicine' is both an oath and a protection for their candidate against any evil. To understand how this 'medicine' works we have to make recourse to mystical powers again. It works through the words spoken to it by whoever administers it provided such a person is imbued with mystical powers. It is for this reason that Chakupewa, the witch, is the one asked to perform this act of oathing. This oathing ceremony should be seen as part of the norming stage of group formation. As is common with group characteristics, Kulwa is bound by rules of this informal group and this is ensured through the oath that is administered [18]. The oath is one of the ways of enhancing group solidarity and cohesiveness in this type of trade.

The recounted events point to the fact that, the setting of this novel is alive with witches and witchcraft activities. Since this novel is written from a realist bearing (note the details with which events are recounted and even naming of certain existing communities such as the Sukuma of Tanzania), it is acceptable to conclude that the writer is informed by real events that take place in the community that the novel is set. The practice does not discriminate. Christian converts and non-christians alike believe in it and practice it. Even Chakupewa the witch (or 'technician', as he fondly sees himself) is a baptized christian whose baptismal name is Paolo (Paul). Dr. Kulwa is a baptized Catholic. The details with which the events are recounted by the actual practitioners are meant to show that witchcraft is a practice that is alive in the society that the novel is set, Tanzania.

Chakupewa's power of lupekeso (use of lightning, a form of witchcraft), a form of mystical power, is seen during one of the campaign rallies. Dr. Kulwa's main opponent, Masanja, senses defeat since he gets very few supporters during the campaigns. To counter this, he (Masanja) orders his campaign agents (supporters) to go and destroy the fort of the Gika where he believes they had administered their witchcraft so that they (the Gika) win the elections. The group of young Gika warriors guarding the fort are got by surprise hence they fail to repulse the group of Galu raiders. The Gika fort and 'medicines' are thus destroyed. It is then that the power of Chakupewa'slupekeso shows itself. The events take place during the day when the sky is clear with no sign of rain at all. However, all over a sudden, some clouds form, a sign of light showers. Instantly, lightning strikes and seriously harms the group of Galu young warriors, two of them fatally. Some become lame while others start making sounds of a wolf which never stops all their lives. Word goes around that it is Chakupewa's doing. This reminds us of Chakupewa's words during the induction meeting. He said he has 'medicine' called lupekeso that can be used to pay back whoever wrongs the other. The Galu have wronged the Gika (Chakupewa is on the side of the Gika) hence Chakupewa applies his mystical powers and we instantly see the power and effects of his lupekeso. People die and others are made lame their entire lives. Such mystical power is simply beyond the comprehension of the common man or even science.

Now, whether the lightning that strikes is of natural causes or as a result of Chakupewa's lupekeso, is hard to tell. Nevertheless, circumstances surrounding the lightning are quite telling. A group of people has been wronged. The group that is wronged is believed to be using powers of witchcraft. The sky is clear with no sign of clouds or rain. Yet in a twinkle of an eye, light clouds form and lightning 
strikes causing harm and fatalities. Who can fail to read some mysterious happening here? It is here that the hard questions beg for answers yet none of us is able to supply the correct and emphatic answers. Does the lightning occur of natural causes or is it "sent" by Chakupewa's lupekeso? The scientific answer of natural cause is not convincing here since the precursor to rain is completely missing on this day. For rain to form and fall, it requires a process that takes quite a while. In this case this does not happen. Instead, as soon as a wrong is committed, clouds form in an instant and there, we see lightning and its effects. Curious again to note in this incident is the fact that the lightning picks out only the trouble makers from the Galu community who attack the Gika. Does this lightning have 'eyes' to see who wronged the other? Apparently yes. Now do we deny witcheraft or do we contend with it as a reality? According to the writer of this novel, we cannot blink at this reality. We have to accept that witchcraft exists; it is real. In line with Gehman, it can be said that Chakupewa's lupekeso is an instance of a witch tapping mystical powers and using such powers to harm society [19].

The main character in Hatima seems to have completely taken to witch practices. To him it is potent enough. This is why during campaigns for his second term as a politician, Dr. Kulwa is found with body parts of an albino boy named Moses. He must have consulted Magadula the sorcerer on which witchcraft would work this time for him. And the witch must have advised him that sacrificing an albino and using body parts of the sacrifice would work for him. Actual acts of sacrificing albinos are a common feature in Tanzania (from media reports). The main story of this text begins with this incident which unfortunately is not developed well enough to help the reader gather adequate insights on this witch practice. However, in brief, it is a pointer to rampant beliefs in witchcraft practices some of which are quite inhuman.

Dr. Kulwa joins witch practices and appears to be set to remain there for good. According to Blau [20], social actors engage in activities as a means of obtaining desired goals. Since Kulwa relied on, among other things, witchcraft to win a political seat, he comes to firmly believe in its efficacy. It delivered the goal he was looking for so he cannot think otherwise of it. Kulwa's interaction with witches and sorcerers has been gainful and that is why he decides to remain in their camp.

\subsection{Witchcraft is a Hoax}

Abdulla [21] explores at length the question of witchcraft. His thesis is that witcheraft is neither here nor there. It is a hoax, an empty practice, non-existent, mere selfish intrigues meant to scare people to the benefit of the witch. He uses his narrator-focaliser, Mr. Msa, to prove his thesis. Mr. Msa is a renowned independent investigator (literary though!) able to unravel difficult mysteries. That is why he is invited by his contemporary and friend, Spekta Seif, a police officer in charge of Giningi police station, to visit him and see for himself superstitious and witchcraft beliefs in Giningi. Whatever is recounted in this second novel highlights the fact that despite the impact of colonialism and modernization, African beliefs and practices regarding witchcraft and traditional healing still remain located at the intersection between the natural world and the supernatural world [22].

Set in Zanzibar island a few years after independence from the British, Kisima cha Giningi is awash with incidents of witchcraft. It is set in a village called Giningi where daily life is full of talk about witcheraft. In his invitation letter to Mr. Msa to visit him at Giningi where he works, Spekta Seif says, "Mimi sasa nimepata uhamisho kuja hapa Giningi, pahala panaposifika kwa uchawi - na kweli, maana hata mazungumzo ya watu wa huku ni uchawi na kulogana" (Since then, I got transferred to Giningi, a place renowned for witchcraft, and indeed it is true since everybody talks about witchcraft). True to Seif's word, as soon as Mr. Msa arrives at the police station where Seif works the first incident he comes in contact with is a report on witchcraft. One of the police officers, Andrea, reports to his boss (Spekta Seif), in the presence of Mr. Msa thus: “... Yule bwana aliyeripoti jana kanzu yake imeibiwa uwanjani pake juи ya kamba amefika stesheni leo. Anasema kanzu imerudishwa pale pale juu ya kamba uwanjani pake, lakini anasema imekatwa vipande vitatu...na kanzu yote inanukia mafusho mabaya sana kama ilifukizwa kwa mavi ya punda makavu" (... The gentleman who reported that his kanzu (Muslim religious habit) had been stolen from the drying lines has visited the police station today. He has reported that the kanzu has been returned to the drying lines at his home, but three pieces have been cut from it... and that the kanzu is emitting an awful smell as if it was dipped in the dry dung of a donkey). This is a report on witchcraft. Such reports are a common occurrence at Giningi police station something that baffles Spekta Seif as the in-charge since he finds it hard to establish the veracity of the claims for a successful court case (Giningi, p. 11).

Before Mr. Msa settles down, another report concerning theft which has occurred at the house of the main character, Mwana wa Giningi, is received. According to the verbal report by Mwana wa Giningi to Spekta Seif concerning the theft, she suspects the thief to be her estranged husband whom they have separated on account that Mwana wa Giningi was intimated to by Mangungu, the reigning witch in Giningi, that he, Vuai, had taken some uramali ('medicines') from him with the intention of causing her death so that he takes possession of the vast inheritance which Mwana wa Giningi has (Giningi, p. 15). Here we come face to face with the witch, those seeking his services and the victim. However, it is interesting that in this case the witch spills the beans of his customer to the intended victim! This is not usual in the practice of witchcraft.

With these two incidents, the stage is set for Mr. Msa to carry out his 'magic', the reason for which he was invited by his long-time friend, Spekta Seif, who respects him so much 
because of his ability to solve difficult riddles. Indeed, it becomes clear that the reason as to why Seif invited Msa is for Msa to help shed light on the practice of witcheraft that is so rampant in Giningi to the dismay of Seif. As a police officer, one of his responsibilities is to deal with lawlessness brought about by many things including witchcraft. However, it appears Spekta Seif is at a loss on how to handle cases of witchcraft. He finds it difficult to collect evidence of the same to enable him arraign culprits before courts of law. As such he ends up receiving complaints but finds his hands tied due to lack of concrete evidence to prosecute the cases. $\mathrm{He}$ cannot do much about the cases.

Henceforth, Mr. Msa investigates two incidents closely related to each other. He has to get that selfish thief who stole Mwana wa Giningi's treasures bequeathed to her by her late father, Makame wa Makame, and the allegation that whoever did this heinous act was also intent on causing her death through witchcraft. We shall not dwell on the first investigation (that of the lost treasures) since it does not have much to do with the subject of our discussion. The second, which is an allegation, is of more interest to us.

After the initial visit to Mwana wa Giningi's house, to gather a report on the scene of crime, the attention of the reader is appropriately turned to what, at first instance, looks unrelated to the theft. In fact Spekta Seif ignores this part since to him it offers nothing of substance in the efforts to get apprehend the thief. However, from the verbal submissions and evidence gathered from the scene of crime, it appears some things need to be made clear. To Msa the investigator, the thief is unlikely to have been Vuai, Mwana's estranged husband. This is because evidence from the scene of crime does not point to him as the culprit. Mwana, the victim, and Spekta Seif are fully convinced that Vuai is the culprit and even Spekta Seif orders that he be arrested. On the way from Mwana's house, Mr. Msa meets his old time friend, the Imam of Giningi. Before parting, Msa requests the Imam to show him Fundi Mangungu's house, which he does. Msa proceeds to Mangungu's house. It is here that the thesis on witchcraft is put to test and the answer found.

On meeting Mangungu the technician, Mr. Msa tests his ability in witchcraft. This follows Mangungu's own submission to Msa that Ali Makame, Mwana's paternal uncle, had sought some witchcraft (in this case sorcery) from him so as to have Mwana separate with her husband, Vuai, and possibly any other evil thing to happen to her so that Ali Makame can take over his late brother's vast cloves estate. Mangungu offered him the witchcraft though Ali did not make his payment. To Mangungu, the witchcraft has already started bearing fruits since Mwana and her husband Vuai are estranged (the reader should remember here that the same Mangungu had intimated to Mwana that it was indeed Vuai, her husband, who had sought witchcraft from him to have her die so that he inherits the vast estate). Herein, the point of view character, Mr. Msa, finds his line of argument. To the point of view character, witches have no powers at all. All they do is to play around with the psychology of people.
They simply set one community member against another thereby creating hatred and enmity. This is what has clearly happened between Mwana wa Giningi and her husband, Vuai. It is Mwana's uncle, Ali Makame, who sought powers of witchcraft from Mangungu. To the point of view character, Mangungu knows that he does not possess such powers. That is why he shamelessly turns around the truth and replaces Ali Makame with Vuai and intimates to Mwana wa Giningi that her husband sought some 'medicines' from him so as to bring about her death. Mangungu knows that this is recipe good enough to set Mwana and her husband on a collision course. This will answer Ali Makame's prayer. On his part, Fundi Mangungu the witch will have the reason to demand for his payment of two shillings. Consequently, Mr. Msa's visit clearly shows that what witches employ is mere playing around with people's psyche. They create fear and animosity in the psyche of people which makes them to always seek solutions to their perceived problems. Whoever seeks witch powers aims at getting whatever he or she has set his or her mind on. On the other hand, the witch is in trade and wants to make the most profit out of his trade. Thus the witch is solving his or her economic problems whereas the one seeking the services has own needs also to be apparently addressed by the powers of witchcraft. From the actions of both Mangungu and Ali Makame we learn one thing about social interaction - people are anxious to benefit one another yet beneath this anxiety rests egoism and utility maximization. Indeed both Pescosolido [17] and Blau [20] argue that in social interaction the individual comes out as an egoistic, rational and utility maximiser. This is exactly what Mangungu the witch and Ali Makame, his client, bring out while interacting through witchcraft. In terms of social exchange, Ali Makame should further be seen as an opportunist out to use a group to quickly achieve his personal goals [23].

Two requests by Mr. Msa serve to illustrate his point. One, he asks Mangungu to tell him the reason that has brought him (Msa) to him (Mangungu). After some argument, it becomes evident to Msa that this witch cannot be able to tell whatever has made him seek his services. To the reader, the meaning that this carries is that witches have no powers that they claim to have. For instance, Mangungu boasts that he had a vision the previous night that Msa would visit him and bring him the two shillings that Ali Makame owed him. Msa questions why the same powers that made Mangungu the witch to see this could fail to enable him have a prior understanding as to the reason that would bring Msa to him. If indeed witches have powers to see one thing, they should be able to see any other thing especially those that are closely related. If Mangungu the technician claims to have powers to 'see' someone coming to settle some payment, such power of vision and foresight should also enable him as a witch to 'see' problems that assail his clients even before thy state them.

To further prove his thesis, Abdulla, through the point of view character (Mr. Msa) administers a simple test on Mangungu the technician. While still with Mangungu, Msa 
asks him to use his powers of witchcraft to tell him (Msa) where the fly that has just settled on Mangungu's thigh will fly to after it leaves his thigh. But still Msa wants Mangungu to apply some 'medicine' so that the fly does not just go anywhere but comes to settle on Msa's nose (Giningi, pp 49-50). This is the stroke that broke the horse's back! Mangungu the technician is left aghast. He is speechless. He gets flabbergasted. He knows he has no powers to know neither where the fly will go nor make the fly settle on Msa's nose as requested. He simply does not have that magical power. That is why he gets evidently infuriated. He is annoyed that this young man, Msa, has come to play tricks on him.

Msa proves to Mangungu the technician that the latter is a cheat. He has no powers of witchcraft other than playing around with people's psyches. It is evident that Mangungu agrees to this discovery by Msa since he is unable to defend his position further and even refunds the money that had been paid to him by Msa. The refund of the money is actually an acknowledgement that there was no practical service rendered. The supposed services to Ali Makame or whoever else were all empty and lacked any efficacy. This is why Msa asks Mangungu and his likes to stop cheating people through practicing empty trades and engage in more meaningful and practical trades that are constructive to society (Giningi, p. 51).

After this exciting and fruitful encounter with mighty Mangungu the technician, Msa explains to his friend, Spekta Seif, that there is nothing like witchcraft. All that happens is playing around with the psyche of unsuspecting people. This is more effective with sorcery. He outlines a number of examples how the supposed witches put to use their tricks through sorcery to make people believe they have been bewitched (Giningi, pp. 56-61). And to rest his point on this thesis, his investigation brings together the two divergent things that were at the start of his visit to Giningi. Initially, Seif had invited him apparently so that the two can share their thoughts on witchcraft. However, beneath this intention, Seif silently wished that being the man he knows, Mr. Msa would go ahead and unravel the mystery that is witchcraft. Beyond unraveling this unstated and silent intention, $\mathrm{Mr}$. Msa, through his dependable and magic-like investigation, reveals that it is not Vuai who caused his estranged wife's death through some witcheraft but that the heinous act was in fact accomplished by her selfish and brutal paternal uncle, Ali Makame, who stabbed her in the chest as she drew water from the community well at Giningi. Mwana's death was not as a result of witcheraft but a case of murder and the murderer is known. With this, Mr. Msa rests his case. There is no witchcraft whatsoever.

The events discussed above come out as quite convincing. Nevertheless there is need to seek a point of convergence between the two positions on witcheraft as depicted in this second narrative. One, it appears it is only the main character, Mr. Msa, who is convinced about witchcraft being non-existent. The rest of the dwellers in Giningi hold the belief in witchcraft. Even the government official (Spekta Seif) who is expected to solve disputes, some arising out of witchcraft, is stunned by the prevalence of the belief and practice of witchcraft. Consequently, it is practical to see that the belief exists in the community and Mr. Msa is a lone ranger. He can hardly be convincing enough about the emptiness that witchcraft is. Mangungu's failure to act to the experiments set before him should be seen as designed by the writer in that way so that the point of view character stands out clearly to persuade the reader that witchcraft is empty. The reader should remember that this is literature and the pen of the writer does not necessarily just jot down social truths and practices. Oftentimes the writer's pen purposes to persuade the reader to 'see' events of a narrative in the way that the writer wishes. Whereas most events in this novel are realistic, the novel itself is based on the popular fiction genre of literature where emphasis is placed on exploiting the psyche of readers by supplying them with many exciting make-believe incidents. Again in this genre, especially the investigative strand, the main character is usually made to stand out as a hero hence is imbued with omniscient characteristics. As such Msa can be seen as an unrealistic character yet the events he interacts with remain realistic since they depict whatever is happening in society. His experiments on the witch are equally trivial and unrealistic. They are used to serve his purpose as the main character as well as the angle of vision of the writer. The experiments do not necessarily take away the mystical powers inherent in the witch. Mangungu the witch is equally depicted as an ineffective joker so that the writer's standpoint is highlighted but not necessarily to utterly deny the practice of witchcraft.

Secondly, majority of the people in Giningi believe in witchcraft. Even with Msa's supposed 'proof', it is unlikely that the practice would die off. It would call for him to carry out mass education in the whole of Giningi to convince the people otherwise. Again, put in the context of Chakupewa's lupekeso (the lightning that struck two people dead and disabled others their entire lives) in Hatima yangu ni ipi?, it is not easy to tell whether Msa would have anything to say about such an instance that goes beyond his simplistic experiments. What Msa dwells on mostly are powers of sorcery and magic which in most cases depend on observable things hence are easy to prove. Msa's experiments, which are dependent on observable things, can also be seen as trivial and unconvincing and cannot be used to verify what witchcraft really portends since it does not rely on observable things. It appears Mr. Musa approaches the subject of witchcraft from a positivist angle where he wants verifiable facts to ascertain the truth and reality of this belief. Yet, as Overring argues, reality can as well be culturally constructed and therefore be relative [24]. To show how truth and reality can sometimes be relative, Niehaus gives the example of villagers of the Lowveld in South Africa who held reality to be dualistic. These villagers acknowledged the existence of a visual, empirical realm of ordinary humans but also a realm of transcendent realities such as ancestors, the Holy Spirit 
and witches who they perceived to be real and present everywhere [24]. In view of this, it is unrealistic to dismiss whatever is culturally held in society as true and real. Witchcraft is one of those realities held in most societies as true. The writer of Kisima can therefore be understood as having set out to promote the investigative genre of literature where the main character is a hero and has to win at all costs. Whereas most events recounted are realistic, since they reflect the actual practice in society, the writer only uses them to promote a genre of literature. The writer uses his pen to slant reality so as to reflect his own point of view.

\section{Social Effects of Witchcraft}

Witchcraft is a social practice and affects society in various ways. From the analysed novels, it is evident that the effects that the writers bring out are mainly negative. In Hatima, for example, witchcraft leads to death as seen in Chakupewa's lupekeso that causes the death of two Galu young men. It also leads to fear and uncertainty among people. People are unable to carry on with their daily business for fear of being bewitched. Masanja, Kulwa's political opponent, is aware that his opponent is using witchcraft during the campaigns and that is why he sends his young men to go and destroy this witchcraft. This should have dampened his campaign spirits since it appears he did not have the services of a more powerful witch to counter Chakupewa's powers.

Effects of witchcraft and superstitious beliefs are even more elaborate in Kisima cha Giningi. Conventional services such as police services are rendered useless in the midst of this practice. The police are unable to deal with the menace decisively since it is impossible to establish it beyond reasonable doubt. It is hard to get evidence against the witch. Consequently, people live in fear of witchcraft being done against them hence they cannot go about their businesses freely. This is clear in the case of Mwana wa Giningi who fears her paternal uncle so much that she is unable to run her clove farming freely. Witchcraft is a source of disharmony in the community. People live lives full of suspicion. They suspect each other of wrong doing hence they cannot be at peace with each other. This is the case between Mwana wa Giningi and her husband, Vuai. This suspicion leads to the break-up of their marriage. On the whole, a community that has witchcraft and superstitious beliefs is one that is not at peace at all.

Whereas Mbiti [9] advances some positive effects of witchcraft, we are hard-pressed to accept such an argument. He singles out three: helping the African peoples to explain misfortunes in society; playing a stabilizing role in society; and, showing that even witches themselves are weak and vulnerable. This is bad logic since it is defeatist to use evil to explain reality. There are many more positive ways in the African culture that can be used to explain the world-view of the Africans other than witchcraft. In its absence, we still can use other aspects of African culture to understand the African's outlook of the world. As argued in this article, one can only accept the sorcerers and magicians on account that their resources can be turned to positive use. And as Mbiti [8] argues elsewhere, mystical power should be employed to the credit of society in such ways as curative, protective, productive and preventive purposes.

\section{Conclusions}

The foregoing discussion on witchcraft, even though from a literary perspective, brings out certain salient issues. Firstly, in both Hatima yangu ni ipi?(What is my destiny?) and Kisima cha Giningi (The well at Giningi), we encounter sorcerers who use herbs and other substances to effect their witchcraft activities. One can positively gather that in any case not all witches are mystical. Some, like Magadula in Hatima, can be treated as mere herbalists who chose to use the chemistry of the herbs for wrong purposes. Such herbalists are actually traditional scientists whose scientific prowess should be harnessed to benefit society. They should be identified and be linked to conventional pharmacists so that they collaborate and benefit the general society positively. Here we see the interface between modern science and traditional practices that are frowned upon and even dismissed yet when understood positively they can be beneficial. We see a nexus between unexplained traditional practices and beliefs and science which can be exploited for social benefits. Secondly, it looks inevitable that people will continue joining secretive groups such as those of witches as long as their desires are not fully answered by conventional means. This is because of the apparent benefits they get from such groups. Finally it is reasonable to argue that to overcome some of the witchcraft practices that are malevolent, we need to carry out mass education in communities with high prevalence of such incidents. Coupled with this is to improve economies of poor societies to cut down on clients of such services since most people seek such services to improve their economic status as is the case of Dr. Kulwa's (Hatima).

We set out to establish the reality or otherwise of witchcraft as depicted by Swahili literary artists. From the perspective of the two artists analysed, it comes out that we are unable to give a concrete answer to the reality of witchcraft. The practice is a mysterious one hence it is not open to scrutiny. Witches hardly share secrets on their powers, apart from claiming they have those powers. It is practically impossible to put one's finger on an act of witchcraft and say how it works or how it worked. Our modern thoughts that are highly guided by science refute the practice. Modern education and science and technology find no place for witchcraft, a practice that cannot be tested in a laboratory to show how it works. Even Christianity or Islam or any other sound faith happens to fail to explain witchcraft or wish it away. The two end up existing side by side since 
both of them operate on one principle, belief in mystical powers. And as Gehman rightly argues, the experience of mystical powers is not only witnessed in Africa since there is a revival of witcheraft, spiritism and the occult in the West and a persistence of belief in mystical powers worldwide [19]. Controversy about the rationality and logic of witcheraft in the modern world will inevitably continue to be witnessed [11]. Consequently, one can only say that it will take quite a long while before witchcraft beliefs and practices are utterly wiped from human society, if ever they will.

\section{REFERENCES}

[1] Hawthorn, J. (2010). Studying the novel. London: Atlantic publishers and distributers Ltd.

[2] Eagleton, T. (1988). "Two approaches in the sociology of Literature" in Critical inquiry, 14.3 (1988) 469-476.

[3] Forsyth, D. R. (2010). Group dynamics, $5^{\text {th }}$ ed. Cengage learning.

[4] Evans-Pritchard, E.E. (1937). Witchcraft, oracles and magic among the Azande. Oxford: Clarendon.

[5] Middleton, J. \& Winter, E. H. (1963). Witchcraft and sorcery in East Africa. London: Routledgeand Kegan Paul.

[6] Bongmba, E. K. (2001). African witchcraft and otherness: A philosophical and theological critique of intersubjective relations. Albany: State University of New York.

[7] Ashforth, A. (2005). Witchcraft, violence and democracy in South Africa. Chicago: The University of Chicago Press.

[8] Mbiti, J. S. (1969). African religions and philosophy. Nairobi:East African Educational Publishers.

[9] Mbiti, J. S. (1991). Introduction to African religion. Nairobi: East African Educational Publishers.

[10] Nehaus, I. (2012). "Witchcraft". Online at www.oxfordbibliographies.com/view/document.

[11] Mesaki, S. "The evolution and essence of witchcraft in pre-colonial African societies" in Transafrican Journal of History
[12] Vol. 24 (1995), pp 162-177 online http://www.jstor.org/stable/24328661.

[13] Mbogo, E. (1999). Ngoma ya Ng'wanamalundi. Nairobi: Standard textbooks graphics and publishers.

[14] Wamitila, K. W. (2003). Pango. Nairobi:Phoenix publishers.

[15] Walibora, K. (2003). Kufa Kuzikana. Nairobi: Longhorn publishers.

[16] Paulines Publications Africa. (1990). The book of "Exodus", The African Bible.

[17] Chipeta, W. (2010). Hatima yangu ni ipi? Shinyanga: Sunrise Publishers.

[18] Pescosolido, B. A. (1992). "Beyond rational choice: The social dynamics of how people seekhelp" in The American journal of sociology, Vol. 97, No. 4, Jan 1992, pp 1096-1138. Retrieved from http:///www.jstor.org/stable/2781508 on March 15, 2017.

[19] Crapanzano, R. \& Mitchell, M. S. "Social exchange theory: An interdisciplinary review" in Journal of management 2005; 31 ; 874 DOI: $10.1177 / 0149206305279602$ online at http://jom.sagepub.com/cgi/content/abstract/31/6/874

[20] Gehman, R. J. (1989). African Traditional Religion in Biblical perspective. Nairobi: Kesho Publications.

[21] Blau, P. M. (1964). Exchange and power in social life. New York: John Wiley \& Sons.

[22] Abdulla, M.S. (1968). Kisima cha Giningi. Nairobi: Evans Brothers Kenya Ltd.

[23] Petrus, T. S. \& Bogpa, D. L. (2007). "Natural and supernatural: Intersections between the spiritual and natural worlds in African witchcraft and healing with reference to Southern Africa" in Indo-Pacific journal of phenomenology. Taylor and Francis Group LLC/Routledge. Retrieved from: http://dx.doi.org/1080.

[24] Hedstrom, P. \& Swedberg, R. (Eds) (1998). Social mechanisms: An analytical approach to social theory. Cambridge: Cambridge University Press.

[25] Niehaus, I. A. A witch has no horn: The subjective reality of witchcraft in the South African Lowveld. Online at http://www.tandfonline.com/loi/cast20. 